Expressed in absoluto units $(35 \cdot 2$ for normals; $79 \cdot 1$ for schizophrenies) or in units relative to the total ATPase (16 per cent for normals; 26 per cent for schizophronies) there is significance $(P=0.001$ and $P=0.06$, respectively). Wo used EDTA $0.1 \mathrm{mM}$ in the incubation medium and wo found that our inhibition (16 and 26 per cent) with glycoside was of the same order as that of Post et al. ${ }^{3}$.

It is possible that these small but definite differences in sodium-potassium-ATPase might be 'magnified' if cerebroeortical biopsy or autopsy material were examined, since it is known ${ }^{4}$ that grey matter contains roughly about 700 times more sodium-potassium-ATPase than rod cells.

Rockofeller Institute,

Philip M. Seeman

New York, 21.

${ }^{1}$ Jarnefelt, J., Biochim. Biophys. Actu, 59, 643 (1962).

- Skou, J. C., First Intern. Pharm. Meeting, 4, edit. by Uvnas, B. (Macmillan, New York, 1963).

${ }^{3}$ Post, R. L., Merritt, C. R., Kinsolving, C. R., and Albright, C. D., J. Biol, Chem., 235, 1796 (1960).

${ }^{4}$ Bonting, S. L., Simon, K. A., and Hawkins, Naomi M., Arch. Biochem. Biophys., 95, 416 (1961).

\section{Penicillin Amidase from Coliforms: its Extraction and some Characteristics}

IT is known that many fungi and some bacteria produce penicillin-splitting amidases or acylases ${ }^{1,2}$. With the exception of the amidase from Streptomyces lavendulae described by Batchelor, Chain, Richards and Rolinson ${ }^{3}$, few details have beon published about these enzymes.

A survey of 310 elinical isolates of E. coli types I and II showed that 40 per cent possessed to varying degree a specific amidase acting at the $\mathrm{CO}: \mathrm{NH}$ linkage and thereby removing the side chain of bonzyl- and phenoxymethyl-penicillin ${ }^{4}$. The root molecule of 6-aminopenicillanic acid (6-APA) was left intact, showing that these amidase-producing coliforms possessed no $\beta$-lactamase; the presence of residual 6-APA was readily demonstrated by reconverting it to benzylpenicillin with phenyl-acetyl chloride. Some of the coliform strains appeared to produce penicillin-amidase in considerable quantity, and one such strain $(C .15)$ was used in an attempt to extract and purify the enzyme. (The strain of $E$. coli used in preparing this enzyme (penamidase) has been accepted by tho Department of Scientific and Industrial Research, Torry, Aberdeenshire, with the number N.C.I.B. 9465.)

Strain $C .15$ was grown in nutrient broth at $37^{\circ} \mathrm{C}$ for $48 \mathrm{~h}$ under inducement from $100 \mu \mathrm{g} / \mathrm{ml}$. benzylpenicillin. Initial efforts at onzyme precipitation by chemical means had yielded inactive products, so $100-\mathrm{ml}$. lots of $C .15$ broth cultures were filtered through cellulose-acetate membranes, and the filtrate vacuum freeze-dried. Approximately $0.5 \mathrm{~g}$ of pale brown flakes, readily soluble in water, was recovered from each $100 \mathrm{ml}$. of culture. $0.2 \mathrm{~g}$ of flake, dissolved in $5 \mathrm{ml}$. water, was dialysed overnight through narrow 'Viskene' sleeves against $1,000 \mathrm{ml}$. water at $4^{\circ} \mathrm{C}$. The resultant pale yellow fluid, about $5 \mathrm{ml}$. volume, was again rapidly vacuum freeze-dried, to yield $4.9 \mathrm{mg}$ of dry yellow powder. A.t each stage throughout the experiment, small aliquots were checked for full amidase activity.

The dialysed powder was found by protein-nitrogen determination to contain 53 per cent $\mathrm{w} / \mathrm{w}$ protein; extractable lipids represented 3.7 per cent by weight. Ashing to constant weight left inorganic residues of $9 \cdot 4$ per cent $\mathrm{w} / \mathrm{w}$; this inorganic residue contained $5 \cdot 1$ per cent potassium, 11 per cent sodium, 6 per cent calcium and no detectable magnesium.

The amidase activity of both the crudo and dialysed powders was estimated by the addition of unit volumes of enzyme solutions to various substrate concentrations (benzylpenicillin solutions ranging from 1 to $100 \mu \mathrm{g} / \mathrm{ml}$.). The system was buffered at $p \mathbf{H} 5.5$ determined. by prior experiment to be optimum, and optimum temperature at $40^{\circ} \mathrm{C}$. At close intervals, so that the initial velocity of reaction might be precisely established, aliquots were removed and the enzyme immediately inactivated by raising mixture temperature to $75^{\circ} \mathrm{C}$ for $10 \mathrm{~min}$.

Residual benzylpenicillin was now assayed by conventional microbiological techniques, using Sarcina lutea as assay organism. It was found that whereas $500 \mu \mathrm{g}$ of the crude product was required to destroy $1 \mu \mathrm{g}$ of benzylpenicillin per $\mathrm{h}$, this amount was split by $6 \mu \mathrm{g}$ of the dialysed enzyme. Graphical determination of the Michaelis constant was then made (Fig. 1) giving $K_{8}=\mathbf{4} \cdot 0$ $\times 10^{-4} \mathrm{~mole} / \mathrm{l}$, at $p \mathrm{H} 5 \cdot 5$ and $40^{\circ} \mathrm{C}$.

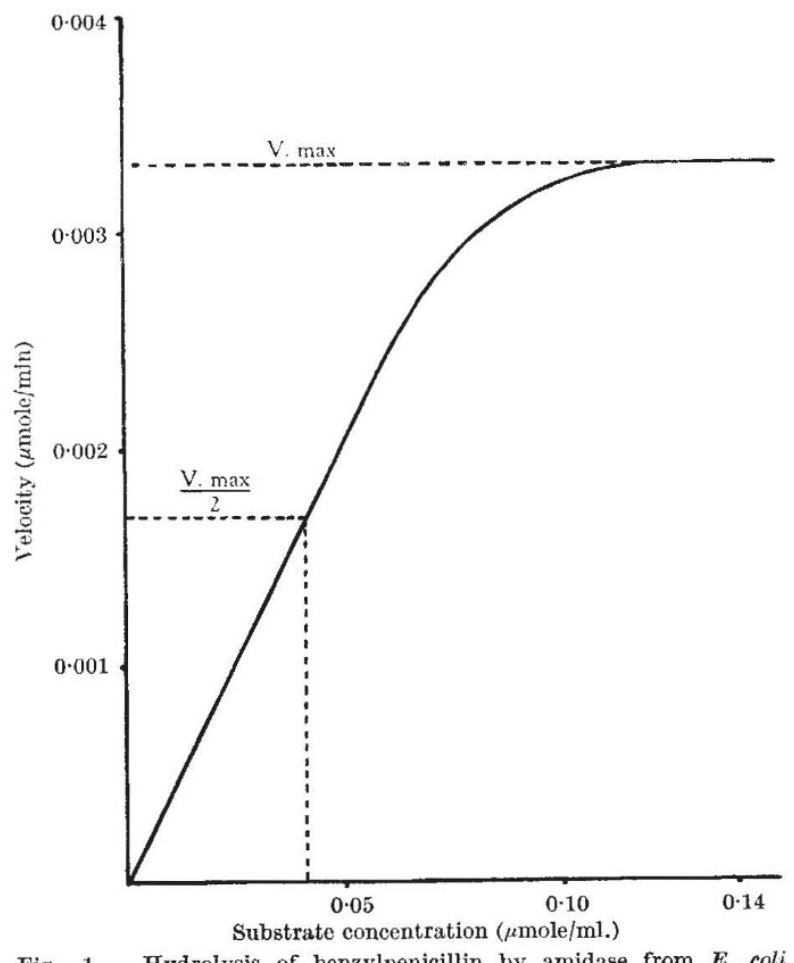

Fig. 1. Hydrolysis of benzylpenicillin by amidase from $\boldsymbol{E}$. coli

The effect of enzyme inhibitors was tested on the dialysed extract; copper, iron, stearic acid and $p$-chloromercuriphenyl sulphonic acid had no inhibitory effect up to $10^{-8}$ M. concentration. 'Versene' showed some inhibition at that concentration.

A proportion of coliforms produce $\beta$-lactamase as well as amidase; in our series of 310 strains of $E$. coli types $I$ and II, we identified 12 per cent in this category. The optimal conditions for this enzyme are different from those for amidase, though benzylpenicillin is an ideal substrate for both. The semi-purified amidase deseribed here had no action on 6-APA in a $p \mathrm{H}$ range 58 , and contained therefore no $\beta$-lactamase. Under the conditions described, amidases from $E$. coli showed maximal activity against benzylpenicillin and phenoxymethyl-penicillin, but possessed also activity of a lower order against other derivatives of 6-APA such as $\alpha$-aminopenicillanic acid (ampicillin) and, in some instances, against derivatives of 7-aminocephalosporanic acid.

\section{R. J. HoLT}

G. T. StewarT

Queen Mary's Hospital for Children and the

Medical Research Council Laboratories, Carshalton.

${ }^{1}$ Batchelor, F. R., Doyle, F. P., Nayler, J. H. C., and Rolinson, G. N., Nature, 183, 256 (1959).

Enclish, A R. McBride, T. C., and Huang, H. T., Proc. Soc, Exp. Biol. Med., 104, 547 (1960).

${ }^{3}$ Batchelor, F. R., Chain, E. B., Richards, M., and Rolinson, G. N., Proe. Roy. Soc., B, 154, 522 (1961).

${ }^{4}$ Holt, R. J., and Stcwart, G. T. (to be published). 